\title{
PERLINDUNGAN HUKUM BAgI PARA PENGGUNA KARTU PROVIDER DI KABUPATEN SUMENEP MENURUT HUKUM POSITIF
}

\author{
SJAIFURRACHMAN \\ Fakultas Hukum, Universitas Wiraraja Sumenep \\ sjafurrachman@yahoo.com
}

\begin{abstract}
ABSTRAK
Masyarakat Sumenep termasuk salah satu pengguna dari beberapa provider yang saat ini ditawarkan oleh para pelaku usaha. Masyarakat sendiri saat ini banyak dirugikan oleh ulah para pelaku usaha yang dengan seenaknya sendiri memotong pulsa konsumen tanpa ada pemberitahuan terlebih dahulu. Bahkan cenderung memaksa para konsumen untuk menggunakan RBT yang mereka sendiri tidak tahu kenapa tiba-tiba terdapat RBT di hpnya. Banyak konsumen mengeluh bahkan tidak tahu harus bagaimana dan harus datang kepada siapa untuk segera meng UNREG RBT yang sudah didapatnya. Bahkan yang tahu UNREGpun harus mengeluarkan biaya sebesar Rp. 2500 hanya untuk segera tidak menggunakan RBT yang ada. Rumusan Masalah yang akan dibahas adalah bagaimana bentuk-bentuk pelanggaran yang dilakukan oleh beberapa provider yang saat ini mulai berkembang di masyarakat, serta bagaimana perlindungan hukum bagi konsumen apabila terdapat pelaku usaha yang memperdagangkan usahanya merugikan konsumen.
\end{abstract}

Kata Kunci : Perlindungan, Hukum, Konsumen Pengguna Kartu Provider.

\section{A. PENDAHULUAN}

Jaman digital saat ini membutuhkan koneksi yang sangat cepat sekali, hal ini yang membuat para pelaku usaha berlomba-lomba membuat provider baru dan juga saling bersaing untuk mendapatkan perhatian dari masyarakat luas.

Kemudahanpun yang dapat diperoleh oleh para pengguna provider ini sangat mudah untuk langsung diakses baik dibantu oleh para penjual maupun diakses sendiri oleh konsumen melalui handphone masing-masing.

Fasilitas yang diberikanpun sangat bervariasi, mulai dari cek pulsa, paket internet, transfer uang serta penggunaan Ring Back Tone (RBT). Hal ini dapat dilakukan melalui handphone masing-masing masyarakat, sehingga kapanpun mau cek pulsa, mau paket internet, serta mau menggunakan RBT yang manapun bisa.

Saat ini cara mengaktifkan RBT sangat mudah, dari sangat mudahnya konsumen bahkan tidak akan sadar bahwa sudah menggunakan RBT. Kalau dulu cara pengaktifan harus mengetik dulu di Short Massage Send (SMS) kemudian dikirim ke nomor masing-masing provider sehingga para konsumen bisa dengan mudah memilah dan memilih mana yang mau dipakai sesuai dengan kebutuhan, sedangkan sekarang para pelaku usaha menggunakan segala cara supaya konsumen menggunakan RBTnya dengan cara terpaksa dan dipaksa. Bahkan tanpa kita mengirim ke nomor yang sudah dipilih oleh para provider konsumen sudah 
bisa menggunakan sendiri RBTnya, hanya dengan menekan angka 5 .

Masalahnya yang terjadi saat ini adalah tanpa kita menekan angka 5 (lima), terkadang langsung terisi dengan sendirinya, kalau terisi RBT mungkin tidak akan menjadi masalah, yang menjadi masalah sekarang adalah setelah terisi RBT pulsa kita akan terpotong dengan sendirinya. Pulsa yang terpotong itupun akan dilakukan oleh pihak provider penyedia RBT tersebut tanpa ada confirmasi dari pemilik kartu tersebut dan tidak tanggung-tanggung pulsa yang terpotong biasanya sekitar $\mathrm{Rp}$. 5000 (lima Ribu Rupiah) sampai Rp. 7500 (Tujuh Ribu Lima Ratus Rupiah).

Hal tersebut sangat merugikan masyarakat sebagai konsumen, kebanyakan masyarakat tidak tahu kalau nomor (kartunya) sudah terisi dengan RBT, bahkan banyak yang tidak menyukai RBT yang disediakan oleh pihak provider. Bahkan banyak masyarakat mengeluhkan tentang RBT tersebut karena biasanya RBT dalam 1 (satu) nomor terisi sampai 4 (empat) RBT tanpa mereka menekan angka 5 (lima) atau mengirim ke nomor yang disediakan oleh pihak provider.

Hal ini sungguh sangat merugikan konsumen karena pulsa mereka akan terpotong secara otomatis, pulsa mereka akan terpotong sedikit demi sedikit sampai habis tanpa mereka sadari, sehingga kebanyakan masyarakat ketar-ketir ketika membeli pulsa dalam jumlah yang banyak.

Bahkan untuk Unreg saja sulitnya setengah mati dan membutuhkan biaya untuk sekali Unreg tersebut, padahal masyarakat sebagai konsumen kebanyakan tidak pernah melakukan registrasi untuk menggunakan RBT tersebut.

\section{B. PEMBAHASAN}

Perlindungan Konsumen adalah segala upaya yang menjamin adanya kepastian hukum untuk memberi perlindungan kepada konsumen.

Konsumen adalah setiap orang pemakai barang dan/atau jasa yang tersedia dalam masyarakat, baik bagi kepentingan diri sendiri, keluarga, orang lain maupun makhluk hidup lain dan tidak untuk diperdagangkan, jelas disini bahwa manusia semua adalah konsumen, karena setiap individu pasti melakukan apa yang namanya transaksi jual beli.

Pelaku usaha adalah setiap orang atau perseorangan atau bada usaha, baik yang berbentuk badan hukum maupun bukan badan hukum yang didirikan dan berkedudukan atau melakukan kegiatan dalam wilayah hukum Negara Republik Indonesia, baik sendiri maupun bersama-sama melalui perjanjian menyelenggarakan kegiatan usaha dalam berbagai bidang ekonomi.

Barang adalah setiap benda baik berwujud maupun tidak berwujud, baik bergerak maupun tidak bergerak, dapat dihabiskan maupun tidak dapat dihabiskan, yang dapat untuk diperdagangkan, dipakai, dipergunakan, atau dimanfaatkan oleh konsumen. 
Jasa adalah setiap layanan yang rumit, maka seharusnya pelaku usaha berbentuk pekerjaan atau prestasi yang harus memberikan apa yang diinginkan disediakan bagi masyarakat untuk oleh konsumen, sedangkan konsumen dimanfaatkan oleh konsumen.

Klausula Baku adalah setiap aturan atau ketentuan dan syaratsyarat yang telah dipersiapkan dan ditetapkan terlebih dahulu secara sepihak oleh pelaku usaha yang dituangkan dalam suatu dokumen dan/atau perjanjian yang mengikat dan wajib dipenuhi oleh konsumen.

Perlindungan yang dimaksud adalah sebagai bentuk asas perlakuan yang sama di depan hukum, perlindungan hukum diartikan oleh peneliti adalah sebagai bentuk payung hukum yang akan menaungi masyarakat dari kesewenangwenangan melalui aturan hukum ataupun perundang-undangan. Jadi perlindungan hukum bagi konsumen adalah sebagai bentuk upaya perlindungan yang diberikan kepada konsumen oleh Undang-undang agar tidak dirugikan oleh pihak-pihak sehingga apa yang di cita-citakan oleh Undang-undang yaitu asas perlakuan sama di depan hukum akan terwujud.

Sebenarnya apabila kita sudah paham apa hak dan kewajiban masing-masing (konsumen dan pelaku usaha) maka peneliti beranggapan nantinya akan mendapatkan hidup yang nyaman. Artinya konsumen disini mengingikan pelayanan yang baik, bagus, fleksibel, serta tidak harus dengan sadar pula memahami hak dan kewajiban dari pelaku usaha, seperti contoh yang terdapat pada pengaturan hak dan kewajiban diatur dalam Undangundang Nomor 8 Tahun 1999 yaitu:

a. hak atas kenyamanan, keamanan, dan keselamatan dalam mengkonsumsi barang dan/atau jasa;

b. hak untuk memilih barang dan/atau jasa serta mendapatkan barang dan/atau jasa tersebut sesuai dengan nilai tukar dan kondisi serta jaminan yang dijanjikan.

c. hak atas informasi yang benar, jelas, dan jujur mengenai kondisi dan jaminan barang dan/atau jasa;

d. hak untuk didengar pendapat dan keluhannya atas barang dan/atau jasa yang digunakan;

e. hak untuk mendapatkan advokasi, perlindungan, dan upaya penyelesaian sengketa perlindungan konsumen secara patut;

f. hak untuk mendapat pembinaan dan pendidikan konsumen;

g. hak unduk diperlakukan atau dilayani secara benar dan jujur serta tidak diskriminatif; 
h. hak untuk mendapatkan kompensasi, ganti rugi dan/atau penggantian, apabila barang dan/atau jasa yang diterima tidak sesuai dengan perjanjian atau tidak sebagaimana mestinya;

i. hak-hak yang diatur dalam ketentuan peraturan perundang-undangan lainnya.

Sedangkan Kewajiban konsumen diatur di dalam pasal 5 Undang-undang Nomor 8 Tahun 1999 Tentang Perlindungan Konsumen yaitu:

a. membaca atau mengikuti petunjuk informasi dan prosedur pemakaian atau pemanfaatan barang dan/atau jasa, demi keamanan dan keselamatan;

b. beritikad baik dalam melakukan transaksi pembelian barang dan/atau jasa;

c. membayar sesuai dengan nilai tukar yang disepakati;

d. mengikuti upaya penyelesaian hukum sengketa perlindungan konsumen secara patut

Hak pelaku usaha itu sendiri juga diatur di dalam Pasal 6 Undang-undang Nomor 8 Tahun 1999 Tentang Perlindungan Konsumen yang berbunyi:

a. hak untuk menerima pembayaran yang sesuai dengan kesepakatan mengenai kondisi dan nilai tukar barang dan/atau jasa yang diperdagangkan; b. hak untuk mendapat perlindungan hukum dari tindakan konsumen yang beritikad tidak baik;

c. hak untuk melakukan pembelaan diri sepatutnya di dalam penyelesaian hukum sengketa konsumen;

d. hak untuk rehabilitasi nama baik apabila terbukti secara hukum bahwa kerugian konsumen tidak diakibatkan oleh barang dan/atau jasa yang diperdagangkan;

e. hak-hak yang diatur dalam ketentuan peraturan perundang-undangan lainnya.

Sedangkan kewajiban dari pelaku usaha diatur di dalam pasal 7 Undangundang Nomor 8 Tahun 1999 Tentang Perlindungan Konsumen yang berbunyi:

a. beritikad baik dalam melakukan kegiatan usahanya;

b. memberikan informasi yang benar, jelas dan jujur mengenai kondisi dan jaminan barang dan/atau jasa serta memberi penjelasan penggunaan, perbaikan dan pemeliharaan;

c. memperlakukan atau melayani konsumen secara benar dan jujur serta tidak diskriminatif;

d. menjamin mutu barang dan/atau jasa yang diproduksi dan/atau diperdagangkan berdasarkan ketentuan standar mutu barang dan/atau jasa yang berlaku; 
e. memberi kesempatan kepada

konsumen untuk menguji, dan/atau mencoba barang dan/atau jasa tertentu serta memberi jaminan dan/atau garansi atas barang yang dibuat dan/atau yang diperdagangkan;

f. memberi kompensasi, ganti rugi dan/atau penggantian atas kerugian akibat penggunaan, pemakaian dan pemanfaatan barang dan/atau jasa yang diperdagangkan;

g. memberi kompensasi, ganti rugi dan/atau penggantian apabila barang dan/atau jasa yang diterima atau dimanfaatkan tidak sesuai dengan perjanjian.

Sebagai bentuk perlindungan kepada konsumen maka undang-undang mengatur sanksi apa saja yang akan diberikan kepada pelaku usaha yang melanggar pasal-pasal yang ada di dalam Undangundang Nomor 8 Tahun 1999 tentang Perlindungan Konsumen. Pengaturan tersebut diatur di dalam BAB XIII Bagian Pertama, Sanksi Administratif.

\section{PENUTUP}

Banyak pelanggaran yang dilakukan oleh para pelaku usaha provider yang sering sekali merugikan konsumen pada khususnya, pelanggaran yang dimaksud adalah berkisar pada pelanggaran hak dan kewajiban konsumen yang sering sekali di abaikan oleh pelaku usaha, salah satu contohnya adalah hak mendapatkan kenyamanan, bagaimana bisa nyaman ketika menelpon saja kadang putus sendiri bahkan suaranya pun tidak jelas, hal ini sangat mempengaruhi dan mengganggu kenyamanan konsumen sebagai pengguna provider

Sebagai bentuk perlindungan kepada konsumen maka Undang-undang mengatur dengan jelas bagaimana hak dan kewajiban masing-masing, bahkan bagaimana sanksi yang akan diberikan oleh Undang-undang tersebut, bukan hanya itu lembaga yang menanganipun yaitu Badan Penyelesaian Sengketa Konsumen sudah siap membantu masyarakat yang membutuhkan.

\section{DAFTAR PUSTAKA}

Ade Maman Suherman, 2004, Arbitrase dan Alternatif Penyelesaian Sengketa, Aspek Hukum dan Ekonomi Global, Ghalia Indonesia, Anggota IKAPI, Jakarta.

Yusuf Shofia, 2002, Penyelesaian Sengketa Konsumen menurut UndangUndang Perlindungan Konsumen (UUPK), Teori dan Praktek Penegakan Hukum, PT. Citra Aditya Bakti, Bandung.

Suyud Margono, SH, 2002, Cetakan Kedua ADR \& Arbitrase, Proses Pelembagaan dan Hukum, Ghalia Indonesia, Jakarta.

Joni Emerson, 2001, Alternatif Pemyelesaian Sengketa Di Luar Pengadilan (Negosiasi, Mediasi, Konsiliasi, Arbitrase), Gramedia Pustaka Utama, Jakarta. 
FAKULTAS HUKUM UNIVERSITAS WIRARAJA SUMENEP - MADURA

Undang-Undang No. 30 Tahun 1999 tentang Arbitrase dan Alternatif Penyelesaian Sengketa.

Undang-Undang Nomor 8 Tahun 1999 tentang Perlindungan Konsumen

Peraturan Mahkamah Agung Nomor 1 Tahun 2006 Tentang Tata Cara Pengajuan Keberatan Terhadap Putusan Badan Penyelesaian Sengketa Konsumen.

Peraturan Mahkamah Agung Nomor 1 Tahun 2002 Tentang Acara Gugatan Perwakilan Kelompok.

$\begin{array}{cr}\text { Keputusan Menteri Perindustrian dan } \\ \text { Perdagangan } & \text { Nomor } \\ \text { 605/MPP/Kep/8/2002 } & \text { tentang } \\ \text { Pengangkatan Anggota } & \text { Badan } \\ \text { Penyelesaian Sengketa } & \text { Konsumen } \\ \text { Pada Pemerintah Kota } & \text { Makassar, } \\ \text { Kota Palembang, Kota } & \text { Surabaya, } \\ \text { Kota Bandung, Kota Semarang, } \\ \text { Kota Yogyakarta, dan Kota Medan. }\end{array}$

Keputusan Menteri Perindustrian dan Perdagangan Nomor 350/MPP/Kep/12/2001 tentang Pelaksanaan Tugas dan Wewenang Badan Penyelesaian Sengketa Konsumen.

Keputusan Presiden No. 23 Tahun 2006 tentang Pembentukan Badan Penyelesaia Sengketa Konsumen. 